\title{
Cognitive Proficiency Analysis of Adventist High School Students Tenth-Grade Aliciously Solve Linear Equations System of Two Variables Reviewed of Gender
}

\author{
Mey Chyntia Yesaya ${ }^{1, *}$ Wilmintjie Mataheru ${ }^{2}$, Christina M Laamena, \\ ${ }^{1,2,3}$ University of Pattimura \\ *Corresponding author.Email: christinmath18@gmail.com
}

\begin{abstract}
Cognitive ability in this research, are steps that students do in solving problems that deal with problem solving. Cognitive abilities seen from the cognitive level of remembering (C1), understanding (C2), applying (C3), analyzing (C4). The study aims to describe a student's cognitive capability in gender problem solving. The study is a qualitative descriptive study that describes the student's cognitive capability in problem solving two variables of linear equations in relation to the female and male gender. The subject in this study is an four students with details of each of the two students of the female gender who have high and low cognitive abilities, and two students of the male gender with high and low cognitive abilities. The data-mining techniques used are problem solving and interview tests. From data analysis it is obtained that students' cognitive capability in problem solving on female gender with high cognitive capability from $\mathrm{C} 1$ to $\mathrm{C} 4$, whereas on female gender low cognitive capability from $\mathrm{C} 1$ to $\mathrm{C} 3$, the male gender high-cognitive capability from $\mathrm{C} 1$ to $\mathrm{C} 4$, whereas the male gender has high cognitive capability from $\mathrm{C} 1$ to $\mathrm{C} 4$, Whereas the male gender has high cognitive capability from levels $\mathrm{C} 1$ through $\mathrm{C} 2$.
\end{abstract}

Keywords: Cognitive ability, Problem solving, Gender.

\section{INTRODUCTION}

Mathematics was one of the subjects taught in school in hopes of becoming a vessel for students to think critical, logical and creative. [1] claims that mathematics is interpreted as a systemically organized and expertly organized branch of science. Furthermore, mathematics is the science of logical reasoning in problem solving. [2] states that problem solving usually leads to a situation that could lead one to resolve the problem but not directly to know how. If a child is confronted with a math problem and the child immediately knows how to settle it correctly, then the problem cannot fall into the category of problem solving. Problem solving is an effort made to solve the problem found. Polya said solving the problem was one of the highest aspects of thinking. So [3] presents two kinds of mathematical problems: (1) problems to find (problems to find) where we try to project all kinds of objects or information that can be used to solve the problem, and (2) problems to prove (problem to accuracy) where we will point to one of the truths of the statement, which is true or false. This kind of matter involves any hypothesis or inclusion of a theory that had to be provable.

That have to solve problems that aren't routine. Agree with that statement, [4] defines problem solving in mathematics asa process applying previously acquired mathematical knowledge to new unfamiliar situations. Problem solving in mathematics is the process of finding answers to a question found in a story, text, tasks and situations in everyday life. [5] says breaking the problem is one of the highest aspects of thinking asa process of accepting the problem and trying to solve it. Moreover, problem solving is an intellectual activity that seeks to solve the problem using existing knowledge. In a condition like this, problem solving is said to be a learning target, students should be able to solve the mathematics problem associated with the real world. Problem solving skills are part of a very important math curriculum or may be said to be a major result of a learning process. [6] states that when a student experiences a conflict he will strive to achieve a new 
balance of solutions to the problem at hand. When a student is able to find conflict and be able to solve it, actually his cognitive abilities have improved. [7] Thus, students with different levels of ability can produce claims that vary depending on the thinking process. This is the focus of the study by describing students' basic thinking when generating claims and processes generating counterexample and compiling them into a deductive proof.

[8] states that cognitive ability in problem solving appears when students collect information from a problem, which is done on the first step (understanding the problem). Such information will be used to create a problem solution design, so that students will solve the problem according to the design created. [9] says that during the process of learning to teach a class, it is common for students to study mathematics only by their teachers, not by exploration. That is what makes most students passive, because in that position the student only accepts the knowledge given by the teacher and also the student is not guided to bring up new ideas in line with the subject. As a result, students are difficult to develop the critical thinking ability that should be had. Some other factors are the cause of lack of cognitive ability, students are accustomed to memorizing without understanding its intent, content, and use. [10] states that activities vital to development in schools, teachers are expected to be able to realize enabling learning, and developing cognitive abilities, in students. [11] names internal factors that affect students' cognitive abilities, in problem solving include: intelligence, motivation, interest, talent, and mathematical as well as gender variability. [12] states gender difference Gender distinctions can affect students' abilities.

[13] explained that male and female students tend to soak differently at school experiences, as male students tend to be more aggressive competitive than female students and respond better to competitive games, while female students tend to prefer learning activities that involve students' involvement in discussion and ideas. Researchers want to do research with cognitive capability based on gender because, there is a difference in gender cognitive capability found based on research, [14] found that men score better than women in math, while the reverse applies to the English exam.

A difference in cognitive abilities between a male and a female, was found in an tenth class of my maluku Adventist. Based on a math study teacher, female students are more domineering. Male students can also get an excellent score as long as they study more math, and are conscientious in working on the problem, particularly the matter of linear two-variable system matter. Linear equations systems of two variables are chosen by researchers because they are difficult, based on questions and answers with teachers of mathematics and the results of researchers' considerations. Linear equations materials two variables were taught to an tenthgrade class of Adventist high school adventists during the full term in accordance with the 2013 curriculum. [15] says that a linear equations system of two variables, which is quite difficult for students to understand, so many students make mistakes in their work on the matter. The reason researchers chose an Adventist high school maluku is because, no research on gender-based cognitive abilities was performed at the school, so researchers felt excited and tried at the school. Based on the above background, researchers find it interesting to do a study with the title "Adventist high school Adventist high school cognitive proficiencies" in solving a problem of a two-gender linear equations system."

\section{RESEARCH METHODS}

This type of research method is qualitative descriptive. Descriptive research aims to present in-depth information on something of the subject. In this study, that information is a description of the process of thinking students. [16] says that qualitative research, which aims to understand the phenomenon of what the subject of research is holistic, and by way of its description in words and language, is a natural special context and makes use of various scientific methods [17] states that a descriptive study, one that attempts to relate current problem solving, based on data. The type of qualitative descriptive research used on this study is intended to obtain information about a student's cognitive capability in gender addressing problems. The research location is at maluu high school, the road. Dr. J. leimena, no.1. The great hative, ambon, research time at this school from June 8 to July 12 .

The sources of data in the study are all my maladventist high school seniors with 2 classes, science and ips with 28 students. Research subjects are four $\mathrm{x}$ graders at my maluku Adventist. The research subject consists of 2 students of the male gender with low abilities, and 2 students of high, low gender. The reason researchers are taking the subject to high abilities, and low is because researchers want to see how it achieves the problems of high performance students, and low.[18] said that if researchers were to take only high - skill students then there would be no comparison of how the students were inferior to the task at hand. In the study, problem solving tests are used, by administering these tests will be analyzed results, as based on indicators of a student's cognitive capability in problem solving. Tests were performed after researchers discovered the subject of research. And after the learning process is over. The problem-solving test was created to find out how female and male students are the subject, to answer a problem. The test in the study, which is the test of students' cognitive capability in open problem solving using a 2problem problem at appendix 5, as in this study, 
researchers only want to see how the student's problem solving is more specific and less specific.

The interview was used as a follow-up after the testing of the students. The interviews in this study an unstructured interview is performed after a problemsolving test. Observation is also used to monitor the development or ability of students in learning. Triangulation is a data validity technique that taps into other data that already exists. These data to compare with existing ones that can reduce bias. There are 3 types of triangulation, namely source triangulation, technical triangulation, and time triangulation. In the study the triangulation used was resource triangulation. According to [19] source triangulation is comparing and reexamining the degree of trust of information obtained through time and different tools. The study conducted by comparing the data of the written test with that of the interview, and it is hoped that the comparative result will be able to discern the reasons for the differences that were later discovered. The analysis of the data used is an analytic descriptive method of describing the data gathered in words, pictures, and not Numbers. Data derived from texts, interviews, field notes, documents, and so forth, are then described as providing clarity for [20] states that analysis had begun since formulating and clarifying the problem.

According to [21], there are three rows of data analysis activities, namely data reduction, presentation of data, and a drawing of such conclusions. 1 . The reduction of data is defined as selection process, attention centrality of simplification, migration, and the transformation of data emerging from field records. 2. The presentation of data is a descriptive of a set of information that gives the possibility of a deduction and action taken. The presentation of qualitative data is presented in the form of a narrative text, with the purpose of being designed to combine information that is framed together and easily understood. 3. A deduction or verification is the final activity of qualitative research. Researchers must come to their conclusions and do verification, both in terms of meaning and truth, as agreed upon by the research facility

\section{RESULT AND DISCUSSION}

Based on the study above, it will be presented in this section what the study will do on the subject's cognitive capability with low cognitive capability from gender to solve the problem based on the problem solving indicator which the polya presented on the problem test in question.

a. On the way of understanding the problem in the way of understanding the problem, receiving information in the same way but with a different cognitive characteristic that $\mathrm{jb}$ reads the matter carefully and carefully several times in a loud and fluid manner, the subject $\mathrm{mm}$ reads the problem carefully and carefully and carefully, ge reads the problem carefully and carefully and carefully, taking it into his own time reading the problem Next, all four subjects respond to what researchers have asked about the information indicated by reading activity, or may be said that the reading activity performed by the four subjects indicates that the four subjects used their visual senses to capture the information they saw. A careful and careful reading of the matter with the distinctive features of learning suggests that the six subjects pay attention to the information received so that the information can be understood and remembered.

This harmonizes with the opinion of [22] as stating that problem solving is It's a very important activity in the mathematical study that A problem usually contains a situation that could impel a person to resolve it. The problem in mathematics isa matter that employs the way, and the procedure which, therefore the problem presented to the student must be consistent with its ability and preparation and its completion process cannot be done by routine procedures. Reading up on the problem-solving test, JB, MM, JR., and GE point out the difference in providing the answer as to the information being known and the question being asked. These four subjects' answers reveal that two subjects, both males 1 and females 1 (JB and GE) subjects provide clear and correct answers so that this would indicate that both subjects are good at processing information, while for both JR. and MM, they are not very good at information.

b. In the planning of the problem solving step, JB and GE say that after reading the problem solving, it is first thought to make the problem first. The reason both subjects make the mystification first is because by creating the problem, the mathematical model is the first and the second equation of solving the problem. From both the subject's answers, it appears that in planning a problem solving, JB and GE are both affected by an inside sense of themselves with a cognitive level of $\mathrm{C} 1-\mathrm{C} 3$, from the thought of making the preconceived process stored in the memory, while the JR and mm tend to be affected by an outside understanding, which is by thinking of an easy way to solve the problem, But hesitantly explain the plan of completion under the pretext of doubt and ignorance.

c. On the way to solving the problem on the way to solving the problem as planned, JB, GE, mm, and JR both subjects use previously understood concepts, formulas, or mathematical operations. Where the subject can solve the problem in accordance with the plan previously created using each method. jb's subject uses a combination of substitution elimination and subject GE uses the first method of elimination and then value substitution. But in the 
process of completion, $\mathrm{mm}$ made a slight miscalculation in the 1 and 2 problem solving which was the mistake of performing a multiplication operation to remove the y.subject's and mm variables to eliminate the use of the method and the algebra operation of the method used. New mistakes were known at the time.

d. In a reexamination of the results obtained in a reexamination of the results obtained, $\mathrm{jb}$ and ge subjects show a common ground by measuring $\mathrm{x}$ and $\mathrm{y}$ into the first ground to prove their work. Both subjects chose the first equation to reexamine the results obtained on the basis that the number used in the equation was of small value, thus making it easier for them to calculate. Jb's subject USES the first equations to reexamine the appropriations of the results obtained, while at this stage subject ge has written nothing in the reply sheet.

Research on jb's subject suggests that $\mathrm{jb}$ meets problem solving indicators and is rated as having a cognitive capability of $\mathrm{c} 1$ to $\mathrm{c} 4$ with equaled sex. According to women's cognitive abilities can develop either by using a learning strategy containing learning activities that leads students to achieving the competence, where students can be actively involved in solving the problem. The cognitive capability of the $\mathrm{c} 1$ to $\mathrm{c} 4$ is from remembering what is learned, understanding or understanding the problem given, applying the problem plan to implementing the known plan at the beginning. Judging from the completion of the problem $\mathrm{jb}$ has been working on, $\mathrm{jb}$ is capable of remembering, understanding, understanding, and establishing what was the original plan for the problem.

This coincides with research that shows that women's subject can immediately understand and be aware of the thought process and can approximate the task's completion time rapidly. In addition to fairweather and the suggests that women are relatively more efficient at understanding and processing information. states that students with the type of women have good cognitive ability tend to solve the problem they face well with the deployment of awareness and thought management. also state that when students experience difficulty in problem solving, it can result from an inability to monitor actively and organize the cognitive processes involved in problem solving. This indicates that cognitive ability plays a key role in the problem solving process.

describe that some measures of achievement and sat tests have demonstrated gender - related differences especially in verbal, spatial, and mathematical capacities. Men seem to excel at tasks that require visualization of objects and women better at tasks that require acquisition and the use of verbal information. Besides jb's subject, ge's subject is also capable and is subject to high cognitive qualification in male gender. The mm subject is able to understand the problem, be able to explain the known and be asked of the given matter. According to the work of the subject ge has good cognitive capability but ge tends to solve the problem by considering the initial concept asa solution, and immediately making the completion measures. Ge also made structured steps that led to right work.

The study [29] which states that differences occur in how male and female students solve math problems. While for cognitive ability it is seen that male students have the same abilities with women only a way of passing on what is done differently, male students tend to have more ability to express job within words than it does on answer paper. So the cognitive abilities of male and female students are distinguished from the way they present things in problem solving as zubaidah has revealed by his research. Male and female cognitive abilities can be distinguished from the cognitive level of c1 to c4 and based on my research, I therefore conclude that male and female students have the same coeffervesf capability from c1 level to $\mathrm{c} 4$ only as distinguished from stating the measures of the working matter or problem given, Male students tend to explain in words without writing while female students tend to write and explain with words on the answer sheet.

It is in line with opinion that says a woman's selfconfidence is better than that of a man at her learning assignments. Furthermore, this harmonizes with $t$ that indicates that men are unable to carry out the plan and reexamine. Whereas women are able to implement a plan and reexamine even if lacking. [23] If argumentation comes to an end when teacher or students reach the final claim to be achieved, then they called it as terminator guide backing. However, if argumentation occurs individually to solve one problem or proving a mathematical statement, the backing that comes from students becomes very important.

\section{CONCLUSIONS}

Deduction Suggestions based on the results of analysis and discussion that have been described in the previous chapter, the researcher concludes that:

a. C1-C4 cognitive level capability displayed by the subject with a low cognitive capacity (JB) in resolving problems based on the following polya steps.

b. C1-C3 cognitive capability on a subject with an enhanced cognitive capacity is reviewed from female gender (MM) in resolving problems based on polya measures as follows.

c. C1-C4 cognitive level subject displayed with a low cognitive capacity is viewed from male gender (GE) in resolving problems based on the following polya steps 
d. C1-C2 cognitive capability on a subject with low cognitive capability is reviewed from male gender (JR) in solving problems.

\section{REFERENCES}

[1] Susanto, D. 2015. Analisis Proses Berfikir Siswa dalam Pemecahan Masalah Terbuka Berbasis Polya Sub Pokok Bahasan Tabung Kelas IX SMP Negeri 7 Jember”, Kadikma Vol. 6, No.1. Hal .25.

[2] Mataheru, W. 2019. Proses Kognitif dalam pemecahan masalah. Bandung: Alfabeta

[3] Hartono, Yusuf. 2014. Matematika: Strategi Pemecahan Masalah. Yogyakarta: Graha Ilmu

[4] Yarmayani, A. 2017. Analisis Kemampuan Pemecahan Masalah Matematissiswa Kelas Xi Mipa SMA Negeri 1 Kota Jambi. Jurnal Ilmiah DIKDAYA

[5] Fauzan (2011). 1 Evaluasi Pembelajaran Matematika: Pemecahan Masalah Matematika Evaluasi matematika. net: UNP, 2011

[6] Laamena, C. M., Nusantara, T., Irawan, E. B., \& Muksar, M. (2018a). Analysis of the Students' Argumentation based on the level of Ability: Study on the Process of Mathematical Proof IOP Conf. Series: Journal of Physics: Conf. Series 1028 (2018) 012156 doi: 10.1088/1742-6596/1028/1/012156

[7] Russefendi (2006),"Kemampuan Berpikir Kritis Siswa dalam Pembelajaran Matematika dengan Menggunakan Model Jucama di Sekolah Menengah Pertama," Jurnal Pendidikan Matematika, vol. 3, no. 1, pp. 92-104, 2015

[8] Kusmiati, Hadi. 2014. Pengaruh Berpikir Kritis Terhadap Kemampuan Siswa Dalam Memecahkan Masalah Matematika (Studi Kasus Di Kelas VII SMP Wahid Hasyim Moga). Junal Eduma. 3(1).

[9] Cahyono, Budi. 2017. Analisis Keterampilan Berfikir Kritis dalam Memecahkan Masalah Ditinjau Perbedaan Gender. Jurnal Aksioma. 8(1). Diunduh di https://media.neliti.com> publication pada tanggal 24 Januari2020

[10] Triyadi. 2013. Kemampuan matematis ditinjau dari perbedaan gender. Skripsi UKSW

[11] Ratumanan, 2015. Perencanaan Pembelajaran. Bandung: Alfabeta
[12] Moleong, L. J. 2010. Metodologi Penelitian Kualitatif, Bandung: Remaja Rosdakarya

[13] Sugiyono. (2014). Metode Penelitian Kuantitatif Kualitatif dan R\&D. Bandung: Alfabeta.

[14] Rina Agustina, "Penyelesaian Masalah Matematika Pada Tipe Kepribadian Phlegmatis," AKSIOMA: Jurnal Program Studi Pendidikan Matematika 3, no. 2 (30 Desember 2014),h.17. Hartono, op.cit, hlm. 4

[15] Widyastuti, Rany. - Proses Berpikir Siswa Dalam Menyelesaikan Masalah Matematika Berdasarkan Teori Polya Ditinjau Dari Adversity Quotient Tipe Climber.\| Al-Jabar: Jurnal Pendidikan MatematikaVol. 6, No. 2

[16] Wijayanti, Okta Irma. 2013. Perbedaan antara Gaya Belajar Siswa Laki-Laki dan

[17] Sulfikarwati, D., Suharto \& Kurniati, Dian. 2016. Analisis Norma Sosiomatematik dalam Pembelajaran Kolaboratif Pokok Bahasan Segitiga dan Segiempat di Kelas VII-C SMP Negeri 11 Jember. Jurnal Edukasi UNEJ 2016, 3(3): 1-4.

[18] Gunawan, Imam \& Palupi, Anggarini Retno. 2008 Taksonomi Bloom - Revisi Ranah Kognitif: Kerangka Landasan untuk Pembelajaran, Pengajaran, dan Penilaian[online].

[19] Arifin, Z. (2011). Penelitian Pendidikan. Bandung: PT Remaja Rosdakarya Offset.

[20] Arikunto, Suharsimi. 2012. Dasar-dasar Evaluasi Pendidikan. Jakarta: Rineka Cipta

[21] Astuti, Puji., Purwoko., dan Indaryani. 2017.Pengembangan LKS untuk Melatih Kemampuan Berpikir Kritis dalam MataPelajarn Matematika di Kelas VII SMP. Jurnal Gantang. II(2).

[22] Beniderject Subanti. -Analisis Kesulitan Metakognisi Siswa Dalam Memecahkan Masalah Sistem Pertidaksamaan Linear Dua Variabel Ditinjau Dari Tipe Kepribadian Guardian, Artisan, Rational, Dan Idealist Kelas X SMKN I Jombang, 2016

[23] Laamena, C. M. Nusantara, T (2019). Prospectiv Mathematics Teachers'argumentation Structure When Constructing Amathematical Proof: The Importance Of Backing. Beta: Jurnal Tadris Matematika, 12(1) 2019: 43-59 DOI 10.20414/betajtm.v12i1.272 